Volume: 01 Issue: 03 | Sep -2019

ISSN: $2663-8525$

Received: 19.07.2019; Accepted 25.07.2019; published: 30.09.2019 at www.editoncpublishing.org

Chesaro, K. D., Editon Cons. J. Arts., Humanit. S. Stud., Double -Blind Peer Reviewed Journal

\title{
Teaching Strategies as Stimulus of Integrated HIV/AIDS Education in the Secondary School Curriculum in Kenya
}

\author{
Daniel Kipyegon Chesaro \\ Moi University, Kenya \\ Email address: sarokira@yahoo.com
}

\begin{abstract}
The purpose of the study was to establish the influence of teaching strategies on the implementation of integrated HIV/AIDS education in the secondary school curriculum. In Kenya, HIV/AIDS remains a significant challenge in all sectors of the economy; education is included. Failure in addressing the impact of HIV/AIDS would, therefore, put the country at the high risk of losing all the gains it has made in the education sector. The Innovation Decision Process Theory and the Health Belief Model guided the study. The study adopted a postpositivist philosophy paradigm. The mixed research design was adopted. The selection of 30 headteachers was made using purposive sampling, whereas 120 teachers stratified sampling and 528 students were selected using simple random sampling. Students' and teachers' questionnaire and head teachers interviews were used to obtain the required data from the respondents. Cronbach's Coefficient Alpha was used to establish the reliability and validity of the research instrument determined using expert judgment. The data was therefore analyzed using inferential statistics and descriptive statistics with the aid of Statistics Packages for Social Sciences version 21. The inferential statistics comprised of Spearman's rank correlation, $t$-test and multiple regression. From the multiple regression model, $(R 2=.810)$ showed that all the predictors used the account for $81 \%$ variation in the implementation of the integrated HIV/AIDS education. The study recommends that the Kenya Institute of Curriculum Development provide in-service training for teachers on HIV/AIDS education. The study also suggests that high priority must be given to training teachers to teach HIV/AIDS.
\end{abstract}

Key Terms: Curriculum, integration, methods of teaching/instruction $* * *$

How to cite this article in APA ( $6^{\text {th }}$ Edition)

Chesaro, K. D. (2019). Teaching strategies as stimulus of integrated hiv/aids education in the secondary school curriculum in Kenya. Editon Cons. J. Arts., Humanit. S. Stud., 1(3), 92-105. $* * *$ 


\section{Editon Consortium Journal of Arts, Humanities and Social Studies (ECJAHSS)}

Volume: 01 Issue: 03 | Sep -2019

ISSN: $2663-8525$

Received: 19.07.2019; Accepted 25.07.2019; published: 30.09.2019 at www.editoncpublishing.org

Chesaro, K. D., Editon Cons. J. Arts., Humanit. S. Stud., Double -Blind Peer Reviewed Journal

\section{Introduction}

HIV and AIDS education plays an important role in reducing discrimination and stigma. Around the world, there is a huge deal of stigmatization and fear of people with HIV. This is fueled by misunderstanding and misinformation. This not only hurts people living with HIV but can also increase the spread of HIV by limiting people from seeking testing and treatment (WHO, 2003). HIV and AIDS education can be useful when targeted at specific groups who are particularly at risk of HIV infection. Great numbers of children around the world are infected with HIV every year. Without treatment, thousands die because of AIDS. In addition, millions of more children who are not infected with HIV are affected by the epidemic indirectly, because of the death and suffering that AIDS causes in their families and their communities. One of the most key health issues facing humanity presently is the HIV/AIDS pandemic. Since the first case was reported in 1981, the scourge has continued unabated to killing millions of people and leaving many of them, (families and communities) suffering (Alcamo, 2002). It is now estimated that 42 million people are living with the virus worldwide. It the same time, it is predicted that by 2020,60 million people will have died of HIV/AIDS (UNAIDS, 2004).

Schools have the potential of being essential instruments for providing HIV/AIDS education and prevention skills (UNAIDS, 2004), which is vital in combating HIV/AIDS. For instance, there is generally an inverse relationship between the level of education and the disease burden for most infectious diseases (Vandemoortele, \& Delamonica, 2000). Furthermore, education levels are strongly predictive of better knowledge, safer behaviour, and reduced HIV infection rates have been described as the single most effective preventive weapon against HIV and AIDS (UNAIDS, 2002; World Bank, 2003). Education improves health outcomes, and educated people are generally healthier than those who are uneducated (Pritchett, \&
Summers, 1996). Teachers should, therefore, exploit the importance of education in combating HIV/AIDS.

According to the Kenya Institute of Education (KIE, 1999), the best strategy in reducing the spread of HIV/ AIDS is to incorporate the Aids education in the existing subjects instead of creating a new subject. According to Kafwa (2005), AIDS education aimed at strengthening and enriching the current curriculum through an infusion. This means that the HIV/ AIDS message will be taught at appropriate points when the main subject is being taught. By infusing and integrating HIV/ AIDS education into all existing subjects, teachers are able to deliver HIV / AIDS topics while staying within the realm of normal subjects (K.I.E, 1999). The commission of higher education (CHE) noted that it is crucial to mainstream HIV/ AIDS education in the 8-4-4 curriculum. This strategy holds a lot of promise in the prevention and control of this pandemic. However, the extent to which this curriculum has been implemented in secondary schools in Kenya has been established by a few scholars such as Kafwa (2005) and documented. Thus, there was a need for this study in the Central Rift region since a similar study has been conducted in Busia District of Western Kenya.

The Ministry of Education of the Kenyan government incorporated HIV/AIDS education in the school curriculum in the year 2003 as a key means of prevention of HIV/AIDS. The curriculum has mainly gone unutilized and affected due to teachers' inexperience and discomfort in teaching sensitive materials (UNESCO, 2005). However, the subject is not tested; hence, it becomes difficult to know the level of knowledge the learners acquire (UNESCO, 2005). A study conducted out in Korogocho slums on youth pregnancy, and risk abortion included respondents between the ages 9 to $15 y$ years. All respondents accepted having engaged in sexual intercourse between the ages of 12 years to 14 years (KHRC \& RHRA, 2010). According to Kafwa (2005), AIDS education in secondary schools was 


\section{Editon Consortium Journal of Arts, Humanities and Social Studies (ECJAHSS)}

Volume: 01 Issue: 03 | Sep -2019

ISSN: $2663-8525$

Received: 19.07.2019; Accepted 25.07.2019; published: 30.09.2019 at www.editoncpublishing.org

Chesaro, K. D., Editon Cons. J. Arts., Humanit. S. Stud., Double -Blind Peer Reviewed Journal

not effectively implemented, although it was designed to enhance life skills and impart knowledge on HIV/AIDS to students. This necessitated the study to be conducted in Central Rift Valley in order to ascertain the implementation of integrated HIV/AIDS education curriculum. Effective implementation of the integrated HIV/AIDS Education in Secondary schools' curriculum would probably equip these children with skills and knowledge to enable them to live positively and to prevent further, more children from becoming infected.

With the introduction of HIV/AIDS education policy, teachers are expected to play a significant role especially in terms of prevention of HIV/AIDS by passing knowledge and skills through teaching HIV/AIDS education in schools (MOEST, 2004). The government policy stipulates that HIV/AIDS should be taught using the integrated approach. In this approach, it is recommended that HIV/AIDS education is taught in all subjects (MOEST, 2004). This presents new challenges to the teachers and school administrators on the effectiveness of the implementation of the integrated HIV/AIDS Education in Secondary schools' curriculum. Despite the introduction and subsequent implementation of integrated HIV/AIDS education in the secondary school curriculum, there are still reported cases of infection among young people aged 15 to 49 years of which secondary school students are among them (M.O.H, 2006). This implies that the integrated "HIV/AIDS" education may not be achieving the intended objectives. This study sought to find out the influence of selected factors on the implementation of the integrated "HIV/AIDS" Education in Secondary schools' curriculum in the Central Rift Region of Kenya.

\section{Methodology}

This study adopted a descriptive survey design. This study was carried out in secondary schools in the Central Rift region of Kenya. The target population of this study was all the headteachers, teachers, and students in public secondary schools in the Central Rift region of Kenya. The accessible population was all the headteachers, Form four teachers and students in the selected schools. From the available population of 105 public secondary schools, purposive sampling was used to select the two national schools, whereas stratified random sampling was used to select various categories of county and Sub-County schools. Purposive sampling was used to select 30 headteachers were 7 from Sub-County school, 14 from county school and 3 from national school. At least 120 teachers were selected using stratified random sampling from the selected schools. In the selection of the form four students, both stratified and simple random sampling was used. Stratified sampling applied to mixed secondary schools whereas simple random applied in the case of single-sex schools. Questionnaires and interview schedules were instruments used in this research to obtain the required data from the respondents. A pilot study was carried out in three schools in the North Rift region of Kenya. It was possible to determine whether the questionnaire and interview schedule provided the data required for the study. The results of the pilot study were useful in clarifying items in the questionnaire and interview schedule and simplifying the instructions. It also yielded an experience that was used to refine the interview schedule and the questionnaire further. Ministry of Education National Council of Science and Technology gave out a permit before carrying out the research. Permission was also obtained from the County Commissioner and the County Director of Education. The researcher visited the selected schools after seeking an appointment with the school administration and explained the purpose of the study to the headteachers. The researcher then administered the questionnaires to the teachers. Further, the researcher conducted a 30-minute interview among the selected headteachers and took notes. After all data had been collected, the researcher conducted data cleaning. The data were coded and analyzed using the Statistical 


\section{Editon Consortium Journal of Arts, Humanities and Social Studies (ECJAHSS)}

Volume: 01 Issue: 03 | Sep -2019

ISSN: $2663-8525$

Received: 19.07.2019; Accepted 25.07.2019; published: 30.09.2019 at www.editoncpublishing.org

Chesaro, K. D., Editon Cons. J. Arts., Humanit. S. Stud., Double -Blind Peer Reviewed Journal

Package for Social Sciences (SPSS). The research yielded both quantitative and qualitative data.

\section{Literature Review}

\section{Impact of HIV/AIDS on Education}

The impact of HIV/AIDS is severe on education and schools. HIV/AIDS affects the different aspect of education, particularly its demand, supply, and quality. HIV/AIDS affects the supply of education by reducing the number of teachers who are able to carry out their work and the resources available for education (UNESCO, 2003). The epidemic is claiming huge numbers of teachers and other education-related personnel. According to UNAIDS (2004), an estimated 860,000 children lost their teachers in subSaharan Africa in 1999. The report further points out that, in Zambia, teachers' AIDS-related deaths are equivalent to about half the total number of teachers trained. Moreover, skilled teachers are not easily replaced, thus affecting the desired teacher - to - learner ratio of one teacher to every 40 learners (UNAIDS, 2004). In Kenya, Swaziland, Zambia and Zimbabwe, the epidemic is significantly contributing to shortages of secondary school teachers (UNAIDS, 2004).

In addition, the HIV/AIDS epidemic affects the quality of education and consequently, on the progression through the education systems (UNESCO, 2003). The quality of education may suffer as more teachers fall victim to the disease. This is because more under-qualified and inexperienced teachers and increased class sizes reduce quality teacher-learner - teacher contact (UNAIDS, 2004). Moreover, the few teachers working are likely to be less motivated and frequently absent as they respond to family trauma or illness. This results in less time for teaching and disruption of classroom schedules (UNAIDS, 2003). Additionally, most families experience a decline in purchasing power, thus making expenditures related to schooling impossible (UNESCO, 2003). The report further points out that the loss of education planners; school sponsors and teacher educators in universities and colleges affect the quality of planning, training and support, thus affecting the quality of education (UNESCO, 2003). HIV/AIDS affects the demand for education. Many HIV/AIDS affected families withdraw children from school to compensate for labour losses, increased care activities and competing expenses (UNAIDS, 2004). In such families, children particularly girls, are withdrawn from school to care for an ill HIV infected family member. Additionally, household income and saving may be depleted, and adults may see little value in investing in education for their children when the future looks so bleak (UNESCO, 2003). Thus, HIV/AIDS reinforces gender inequities, deepens poverty and threatens future generations (UNAIDS, 2004). HIV/AIDS epidemic results in reduced fertility and death of young people. This results in fewer school-age children, thus decreasing the social demand for education (UNAIDS, 2004).

A very important role is played by education in human development through the process of empowering people to improve their well-being and to participate actively in nation building. Kenyans recognized the importance of education in promoting human development and arrived at a consensus to give education a high priority in their development programmes. After political independence, the government proposed to wage a spirited war against ignorance, poverty, and disease through Education. Education has a role to play in the prevention and handling of the pandemic. That is because education has the potential to do the following, in case of infection, provide knowledge, which will inform self-protection, constructive value system, foster the development of a personally held, inculcate skills that will facilitate self-protection, promote behaviour that will lower infection risks and enhance capacity to help others to protect themselves against risk. Besides this, when infection has already occurred, education still has the potential to strengthen the ability, to cope with personal/family infection, promote caring for those who are infected, reduce stigma, silence, shame, 


\section{Editon Consortium Journal of Arts, Humanities and Social Studies (ECJAHSS)}

Volume: 01 Issue: 03 | Sep -2019

ISSN: $2663-8525$

Received: 19.07.2019; Accepted 25.07.2019; published: 30.09.2019 at www.editoncpublishing.org

Chesaro, K. D., Editon Cons. J. Arts., Humanit. S. Stud., Double -Blind Peer Reviewed Journal

discrimination, help young people stand up for the human rights that are threatened by their personal/family health conditions. Education has a big role to play, even when death has occurred due to HIV/AIDS. This is because it has the potential to; assist in coping with grief and loss, support the assertion of personal rights, and help in the organization of life after the death of family members (Whiteside, \& Sunter, 2000). All teachers should be trained on HIV/AIDS awareness campaign as part of their training programme. Items such as plays and even real-life experiences should back the presentation. The present study seeks to investigate the effectiveness of the implementation of the integrated HIV/AIDS Education in secondary schools.

\section{Teaching approaches to HIV/AIDS education}

Whether a certain education system is of low or high quality can be judged by input, output and process. Due to financial constraints, the government of Ethiopia chose to improve the quality of education through the teaching and learning process, which is assumed cost-effective. The study is aimed to find the extent to which innovative approaches of teaching and learning are employed in a primary school in Ethiopia. The descriptive survey research method used study found most teachers still use lecture method dominates most classes (Derebssa, 2005). For education to take a positive role in learner development, Lockheed and Verspoor (1999) stated that it has to meet minimum quality standard required in terms of minimum inputs (qualified teachers, community support, materials, parent support and facilities). It must also be a process (effective leadership, accountability, Ministry of Education, community participating productive learning and teaching, a learner assessment) and output (societal, individual returns and high student learning). Dakar Framework for Action (2007) for quality education was seen as a prime condition for providing Education for All (EFA). It affirms that quality is the heart of education and goals to commit nations to provide education of good quality. Goal six includes a commitment to improving all aspects of quality education and ensuring excellence for all so that measurable and recognized learning outcomes are achieved by everyone especially literacy, numeracy and life skills (UNESCO, 1990).

For scholars, the quality of education depends largely on learning and teaching activity. It is, therefore, cognizant to the situation that applies to learners-centred pedagogy is necessary (Cook and Cook, 1998). Learning by action is a theme stressed by several educators since John Dewey's time where learners engage in an active quest in learning new ideas (Dewey, 1966). Silcock and Brundert (2001) define learner-centred approaches as those where tutor guides facilities learners other than asserting control, towards targeted teaching goals. Active learning and teaching involve the use of strategies, which maximize opportunities for interaction. Some literature refers to interactive rather than active approaches.

AIDS education in Kenya is based on a "life skill" approach. This approach puts into focus relationship issues, scientific aspect of HIV and social side effect about the infection. But since the teachers of Kenya are more used to teaching subjects in a factual and academic fashion, this makes many finding difficulties in addressing the topic in a manner that was relative to the social realities of learners' lives (Boler, \& Jellema, 2005). School education is mostly focused on examinations. Teachers are therefore used to inundating learners with figures and facts, whereas AIDS education requires that teachers engage students in active learning sessions (Boler et al., 2003). Effective AIDS education motivates young people to take part and engage with the information being presented to them by offering opportunities to apply it (UNESCO, 2009). Role-play and Group work are particularly essential methods in which students might discover the practical aspects of the information they are given. These methods allow students an opportunity to put into practice and build skills - saying 


\section{Editon Consortium Journal of Arts, Humanities and Social Studies (ECJAHSS)}

Volume: 01 Issue: 03 | Sep -2019

ISSN: $2663-8525$

Received: 19.07.2019; Accepted 25.07.2019; published: 30.09.2019 at www.editoncpublishing.org

Chesaro, K. D., Editon Cons. J. Arts., Humanit. S. Stud., Double -Blind Peer Reviewed Journal

"No" to sex. Active learning approaches are broadly considered the most effective way for young people to learn health-related and social - skills (UNICEF, 2009). Furthermore, active learning approach offers a chance to make AIDS education lessons enjoyable. AIDS education classrooms can be constructed to involve games, quizzes drama, for example - and can still be very effective learning sessions.

A study conducted in India on educational response to HIV/AIDS indicated that HIV/AIDS education is included in science lessons thus taught purely on the biological aspect of those subjects (Global Campaign on Education, 2005). This method is advantageous in that teachers who have not been trained to teach HIV/AIDS easily adapt to it. In the US, AIDS education is conducted in the wider framework of sex education (Global Campaign on Education, 2005). Distribution and Preparation of scientifically accurate, good quality learning and teaching materials and culturally appropriate on HIV/AIDS education would facilitate effective implementation of HIV/AIDS studies (Bennel 2001). Teachers need ongoing support in the introduction of the inquiry-based right-oriented type of education on HIV/AIDS. Many of these approaches motivate active participation and skill development (Boler et al., 2003).

According to Kafwa (2005), due to the HIV/AIDS epidemic, the school role appears to be changing. Traditionally, it was expected that schools would provide education to the whole child in the broad spectrum of the social, intellectual, cultural, moral, aesthetic, physical and spiritual domains. A crucial problem passed by HIV/AIDS education regarding educators, most of them shy away from dealing with the underlying cases of adolescent sexuality. When the subject was approached, they present content with an abstract presentation of themes and principles. In the process, educators are unaware that there is a gap of communication between them and youth (UNESCO, 2008). Families, friends, the wider community, popular culture and mass media all influence young people, and this is important since they convey correct educational information about HIV and AIDS (UNESCO, 2009). The opinion is divided between education providers who take the abstinence-only approach to sex education and those who advocate a more comprehensive approach. Which method is favoured significantly affects how the youth gets educated about HIV and AIDS (UNESCO, 2009). Sex education that puts focus on abstinence is based on the belief motivating young people to abstain from sex until marriage is the best way to prevent HIV infection. This approach discourages AIDS education by not providing information about how young people can protect themselves from HIV infections when they do choose to have sex. It is important for HIV prevention that schools provide a comprehensive sex education, which educates about the importance of using a condom as well as promoting delayed introduction to sex (UNAIDS/WHO 2008).

\section{Teaching Styles used in an Integrated Curriculum}

The purpose of teaching is to reach learners of all spheres of life in the classroom. Educators are encouraged to ensure that they pursue a course that will help learners to follow this route to reach their destination (Fleming, 2009; Coffield et al., 2004). The findings from the teaching styles inventory reflect the following in descending sequence of educator teaching style preference: Analytical-, reflective-, global-, impulsive-, individual, visual- and group teaching. However, there was little difference between the number of times educators opted for analytical, reflective and global teaching styles. Analytical educators are very methodical and systematic in their teaching as they pay attention to existing facts and formulas (Anderson, 2007). Reflective teachers, on the other hand, often involve learners in interrogating existing beliefs and practice in light of the grounds that give support to them and consequences that could follow behaviour (Pickett, 2010). Global teachers, similarly to analytical, tend to be 


\section{Editon Consortium Journal of Arts, Humanities and Social Studies (ECJAHSS)}

Volume: 01 Issue: 03 | Sep -2019

ISSN: 2663-8525

Received: 19.07.2019; Accepted 25.07.2019; published: 30.09.2019 at www.editoncpublishing.org

Chesaro, K. D., Editon Cons. J. Arts., Humanit. S. Stud., Double -Blind Peer Reviewed Journal

methodical in their teaching. However, they also have reflective tendencies as they allow the sharing of personal experiences as a way of making connections between school content and real-life experiences (Anderson, 2007).

Educators could adapt their teaching style to the learners' learning style preference or compromise equilibrium between the teaching-and learning styles mostly preferred by both parties (WCED, 2000). It is important for educators to understand they are not dispensers of knowledge but facilitators that facilitate the teaching and learning process. It might be important to know that it is not what learners learn but, how they learn what (the content), to make sense thereof or apply the knowledge intelligently (Jacobs, 1997; Caine, \& Caine, (1991). Reported cases of HIV/AIDS infection on secondary school students closely linked to sensory learning theory is the idea that people learn in different ways, which has been explored over the last few decades by educational researchers. Research indicates that when it comes to encouraging certain behaviour changes among young people in the era of HIV/AIDS, educators' knowledge of learning styles is crucial (Remberk, \& Gunnarsson, in press). It has been established that individuals prefer a particular learning style. There are weaknesses and strengths in each of these styles. In addition, the preferred learning styles could fluctuate from lesson to lesson, one to another and even among subjects (Gilbert, \& Swanier, 2008).

Therefore, learning can be enhanced when educators use a wide repertoire of teaching styles that could match a wide range of learning techniques in their classrooms. In this way, educators can build on strengths and work towards minimizing weaknesses to improve the quality of learning (Pickett, 2010). Consideration of learning styles is particularly beneficial when dealing with subject matter that is meant to change consciousness, but may not be immediately experienced as fun or safe by educators (Penumal, 2008; Anderson, 2007). Given the fact that many educators do not necessarily feel comfortable teaching HIV/AIDS-related topics because they are forced to bring what is regarded as private into public (sex and the private body) (Baxen, \& Breidlid, 2009); knowledge of and appealing to different learning styles while teaching is essential. According to Kafwa (2005), to be able to integrate HIV/AIDS education and awareness into the curriculum the different teaching and learning styles could be combined to convey the importance of the effects and consequences of HIV/AIDS. Teaching and learning processes can be designed and implemented with the aim that learners learn differently, and this important message needs to be conveyed to all learners. Fleming (2009) and Coffield et al. (2004) are of the opinion that it could be beneficial to think of the individual differences among students and to work towards including the activities that promote variety and interest of all the students in educational programmes.

In addition to activist, pragmatist, theorist and reflector learning styles, learners also prefer the kinesthetic, tactile, visual and auditory learning styles. A kinesthetic learner is described as one who prefers frequent mobility while learning a tactile (or tactual) one needs "hands-on learning and manipulative" (Hardee et al., 2009). An ideal teaching and learning strategies for these two groups of learners should involve their hands and bodies and allow them to learn while on their feet. Role-playing and drama during teaching learning around HIV/AIDS could suit kinesthetic and tactile learners as confirmed in a study by Kamo et al., (2008).

Davis (2007) defines visual learners as those who prefer seeing and making sense of visual depictions such as pictures and graphs. Learning for these kinds of learners' best takes place if they see and watch demonstrations. In the context of HIV/AIDS in Life-skills curriculum, these learners would benefit tremendously from, for example, watching video clips, interpreting statistics and reading 


\section{Editon Consortium Journal of Arts, Humanities and Social Studies (ECJAHSS)}

Volume: 01 Issue: 03 | Sep -2019

ISSN: $2663-8525$

Received: 19.07.2019; Accepted 25.07.2019; published: 30.09.2019 at www.editoncpublishing.org

Chesaro, K. D., Editon Cons. J. Arts., Humanit. S. Stud., Double -Blind Peer Reviewed Journal

case studies. Auditory learners are good listeners who prefer lectures, talking things through and listening to what others have to say (Anderson, 2007).

Action learning is the approach linking the world of learning with the world of action through a reflective process within small co-operative groups known as 'action learning sets' (McGill, \& Beaty, 1995). These 'sets' can meet regularly to work on individual members' real-life issues (HIV/AIDS awareness) with the target of learning with and from each other. Action learning is best for finding solutions to problems that have the wrong answer since the necessary questioning can be facilitated by people learning with and from each other in action learning 'sets'. Learning through one to one debates or role-playing are ideal strategies that could enhance learning, as implied by this theory. The findings of the learning styles inventory have indicated that learners are adaptable to the different styles of learning, but preference for styles of learning was expressed in the following descending order: kinesthetic, auditory, tactile, visual, individual and group learning. The kinesthetic and auditory learning styles were the most dominant. According to Hardee et al. (2009), kinesthetic learner needs frequent mobility. Auditory learners are good listeners who prefer lectures, talking things through and listening to what others have to say (Anderson, 2007).

Kinesthetic learning is learning through doing, action, activity, participation preferred by learners as this is the last strategy on the educators' list of preference to teach. Even though learners prefer the kinesthetic- and auditory learning style, educators prefer the visual, non-verbal and verbal style of teaching. Through verbal guidance and questioning, the provision of audio props and demonstration of higher levels of attainment, the educator supports the learner to attain the desired outcome of HIV/AIDS education and awareness. A consequence of such support is sustained learner interest (Kamo et al., 2008). Since classrooms are made of many individual learners, at any given time, learners with all the learning styles are in classrooms. Therefore, while some are dominant, it does not mean a teacher should ignore the less common styles of learning. In that way, all learners would be able to participate in the integrated HIV/AIDS education and awareness instead of isolating the teaching and learning styles (WCED, 2000). If teaching is appropriately targeted to address all learning styles and are properly combined and administered, the desired outcomes might easily be achieved in an integrated approach to HIV/AIDS education and awareness.

Relationship between teaching styles and learning styles The study has made clear that whereas a majority of educators idealise an analytical, reflective and global teaching-learning process, learners prefer a kinesthetic and auditory teaching-learning process. As it was explained earlier, an analytical-reflective-global educator is often methodical, systematic involving and supporting learners to make connections between content and real-life situations. Kinesthetic-auditory learners, on the other hand, prefer more learner-centred activities, which allow them to make sense of learning topics and the learning process entirely through movement and hearing. Examples of such events, according to Hardee et al., (2009), could be drama, role-playing debating, and so forth. What could be the implication of the vast differences in educators and learners idealization of teaching learning on how the teaching and learning process can be enhanced to efficiently achieve learning outcomes envisaged in the Lifeskills curriculum on topics related to HIV/AIDS awareness and education? Baxen (2006) speaks to the same point that has been highlighted by this study. She argues that in the development and delivery of messages around HIV/AIDS simplistic associations continue to be made about the relationship between the mediators (educators), the nature of HIV/AIDS knowledge messages and those the messages are meant to target. Baxen and Breidlid (2009) point out those learner-driven lessons do not always work 


\section{Editon Consortium Journal of Arts, Humanities and Social Studies (ECJAHSS)}

Volume: 01 Issue: 03 | Sep -2019

ISSN: $2663-8525$

Received: 19.07.2019; Accepted 25.07.2019; published: 30.09.2019 at www.editoncpublishing.org

Chesaro, K. D., Editon Cons. J. Arts., Humanit. S. Stud., Double -Blind Peer Reviewed Journal

as well as those that are teacher-driven. If learners in this study prefer kinesthetic modes of acquiring knowledge, educators probably need to reconsider the extent to which they could balance their methodical, systematic strategies in delivering HIV/AIDS messages with learner-driven input and interrogation of messages. Therefore, educators could relinquish the authoritative approach and allow learners to structure their learning in such a way that it will be beneficial for them to have social interaction and learn responsibly (Donald et al., 2006). Working with learners as opposed to on or against them requires the educator to cede some degree of control of the learning content (Brady, \& Scully, 2005)

\section{FINDINGS AND DATA ANALYSIS \\ Influence of Teaching Strategies}

The finding showed that most teachers appropriately used question and answer method to make learners understand the content on HIV/Aids in their school. Most of the teachers 111(95.7\%) agreed that the use of resource persons was appropriate in teaching integrated HIV/AIDS content in the secondary school curriculum, with $2(1.7 \%)$ disagreed and $2.6 \%$ undecided on the use of resource persons in teaching HIV/AIDS content. The finding showed that most teachers identified the use of resource persons as appropriate in teaching integrated HIV/AIDS content in the secondary school curriculum. Most of the teachers 108(93.1\%) agreed that the use of ICT equipment and software like TV, CDs were appropriate for teaching HIV/AIDS, with 6(5.2\%) disagreed and 2(1.7\%) undecided on the appropriateness of ICT equipment and software in teaching HIV/AIDS content. The finding showed that most teachers identified the use of ICT equipment and software like TV, CDs appropriate for teaching HIV/Aids. On average $54(46.6 \%)$ agreed that lecture method was appropriate in teaching integrated HIV/Aids content in secondary school, with $49(42.3 \%)$ disagreed and $13(11.2 \%)$ undecided on the appropriateness of lecture method in teaching HIV/Aids content. These showed that averagely teachers identified the use of the lecture method was appropriate in teaching HIV/Aids content in secondary school.

Table 1: Influence of Teaching Strategies on Implementation of Integrated HIV/AIDS Education

\begin{tabular}{|c|c|c|c|c|c|c|c|c|c|c|c|c|}
\hline \multirow[t]{2}{*}{ Statement } & \multicolumn{2}{|c|}{$\begin{array}{l}\text { Strongly } \\
\text { agree }\end{array}$} & \multicolumn{2}{|c|}{ Agree } & \multicolumn{2}{|c|}{ Undecided } & \multicolumn{2}{|c|}{ Disagree } & \multicolumn{2}{|c|}{$\begin{array}{l}\text { Strongly } \\
\text { disagree }\end{array}$} & \multirow[t]{2}{*}{ Mean } & \multirow[t]{2}{*}{ SD } \\
\hline & Freq & $\%$ & Freq & $\%$ & Freq & $\%$ & Freq & $\%$ & Freq & $\%$ & & \\
\hline $\begin{array}{l}\text { Question and answer method if } \\
\text { appropriately used makes learners } \\
\text { understand the content HIV/Aids in } \\
\text { secondary school }\end{array}$ & 27 & 23.3 & 62 & 53.4 & 15 & 12.9 & 9 & 7.8 & 3 & 2.6 & 3.871 & 0.947 \\
\hline $\begin{array}{l}\text { Group discussion is quite appropriate in } \\
\text { teaching integrated HIV/Aids }\end{array}$ & 31 & 26.7 & 76 & 65.5 & 4 & 3.4 & & & 5 & 4.3 & 4.147 & 0.676 \\
\hline $\begin{array}{l}\text { Use of resource persons is appropriate in } \\
\text { teaching HIV/AIDS content in the } \\
\text { secondary school curriculum }\end{array}$ & 65 & 56.0 & 46 & 39.7 & 3 & 2.6 & 2 & 1.7 & & & 4.500 & 0.639 \\
\hline Overall Mean & & & & & & & & & & & 3.978 & 0.855 \\
\hline
\end{tabular}




\section{Editon Consortium Journal of Arts, Humanities and Social Studies (ECJAHSS)}

Volume: 01 Issue: 03 | Sep -2019

ISSN: $2663-8525$

Received: 19.07.2019; Accepted 25.07.2019; published: 30.09.2019 at www.editoncpublishing.org

Chesaro, K. D., Editon Cons. J. Arts., Humanit. S. Stud., Double -Blind Peer Reviewed Journal

Correlation on the Influence of Teaching Strategies

Spearman Correlation Coefficient was employed to determine the influence of appropriateness of the teaching strategies used by teachers in the teaching of the integrated HIV/AIDS education in the Secondary school curriculum, as shown in Table 1. The relationship relationship between the appropriateness of the teaching strategies employed by teachers and the effectiveness of the implementation of the integrated HIV/AIDS education in the Secondary school curriculum was strong and positive $[r=.227, n=116, p<.05]$, this indicated that an increase inappropriateness of the teaching strategies employed by teachers on the effectiveness of the implementation of the integrated HIV/AIDS education in the Secondary school curriculum.

Table 2: Correlation on the Influence of Teaching Strategies on Implementation of Integrated HIV/AIDS Education

\begin{tabular}{|l|l|l|l|r|r|}
\hline \multirow{3}{*}{$\begin{array}{l}\text { Spearman's } \\
\text { rho }\end{array}$} & Implementation & $\begin{array}{l}\text { Correlation } \\
\text { Coefficient }\end{array}$ & 1.000 & $.227^{*}$ \\
\cline { 3 - 6 } & & $\begin{array}{l}\text { Sig. (2- } \\
\text { tailed) }\end{array}$ & .014 \\
\cline { 3 - 6 } & \multirow{2}{*}{\begin{tabular}{l} 
Strategies \\
\cline { 3 - 6 }
\end{tabular}} & $\begin{array}{l}\text { Correlation } \\
\text { Coefficient }\end{array}$ & $.227^{*}$ & 1.000 \\
\cline { 3 - 5 } & $\begin{array}{l}\text { Sig. (2- } \\
\text { tailed) }\end{array}$ & .014 &. \\
\hline
\end{tabular}

*. Correlation is significant at the 0.05 level (2-tailed).

b. Listwise $\mathrm{N}=116$

Thus, the more appropriateness of the teaching strategies learning style, educators prefer the visual, non-verbal and employed by teachers, the more effective the verbal style of teaching. Through verbal guidance and implementation of the integrated HIV/AIDS education in the Secondary school curriculum. The relationship between the appropriateness of the teaching strategies employed by teachers and the effectiveness of the implementation of the integrated HIV/AIDS education in the Secondary school curriculum was strong and positive. The findings agree with Hardee et al. (2009) that a kinesthetic learner needs frequent mobility. Auditory learners are good listeners who prefer lectures, talking things through and listening to what others have to say (Anderson, 2007). Kinesthetic learning is learning through doing, action, activity, participation preferred by learners as this is the last strategy on the educators' list of preference to teach. Even though learners prefer the kinesthetic- and auditory questioning, the provision of audio props and demonstration of higher levels of attainment, the educator supports the learner to attain the desired outcome of HIV/AIDS education and awareness. A consequence of such support is sustained learner interest (Kamo et al., 2008).

Since classrooms are made of many individual learners, at any given time, learners with all the learning styles are in classrooms. Therefore, while some are dominant, it does not mean a teacher should ignore the less common styles of learning. In that way, all learners would be able to participate in the integrated HIV/AIDS education and awareness instead of isolating the teaching and learning styles (WCED, 2000). Teaching is appropriately targeted to 


\section{Editon Consortium Journal of Arts, Humanities and Social Studies (ECJAHSS)}

Volume: 01 Issue: 03 | Sep -2019

ISSN: $2663-8525$

Received: 19.07.2019; Accepted 25.07.2019; published: 30.09.2019 at www.editoncpublishing.org

Chesaro, K. D., Editon Cons. J. Arts., Humanit. S. Stud., Double -Blind Peer Reviewed Journal

address all learning styles and are properly combined and administered the desired outcomes might easily be achieved in an integrated approach to HIV/AIDS education and awareness.

The findings agree with Pickett (2010) that learning can be enhanced when educators use a wide repertoire of teaching styles that could match a wide range of learning techniques in their classrooms. Consideration of learning styles is particularly beneficial when educators (Penumal, 2008; Anderson, 2007) experience dealing with subject matter that is meant to change consciousness but may not immediately felt as fun or safe. Many educators do not necessarily feel comfortable teaching HIV/AIDS-related topics because more often than not they are forced to bring what is regarded as private into public (sex and the private body) (Baxen, \& Breidlid, 2009). To be able to integrate HIV/AIDS education and awareness into the curriculum, the different teaching and learning styles could be combined to convey the importance of the effects and consequences of HIV/AIDS. Fleming (2009) and Coffield et al, (2004) are of the opinion that it could be beneficial thinking about the individual differences among learners and working towards including activities that have variety and interest of all the learners in educational programmes. Learning and teaching activities can be designed and implemented with the aim that learners learn differently, and this important message needs to be conveyed to all learners.

Derebssa (2005) agree that most teachers continue to use lecture method dominates most classes. The study aims to find the extent to which innovative approaches of teaching and learning are employed in a primary school in Ethiopia. Since Kenyan teachers are mostly used to teaching subjects in a factual, academic fashion, many find it challenging to address the topic in a way that was relevant to the social realities of learners' lives (Boler, \& Jellema, 2005). School education is mostly focused on examinations. Teachers are therefore used to inundating learners with data, whereas AIDS education requires that teachers engage students in active learning sessions (Boler et al., 2003). Effective AIDS education encourages youth to participate and engage with that information presented to them by providing them with the opportunity to apply it (UNESCO, 2009). Group work and role-play are particularly essential methods in which students might discover the practical aspects of the information they are given. These methods allow students an opportunity to put into practice and build skills - saying "No" to sex. Active learning approaches are broadly considered to be the most productive way for young people learning health-related and social - skills (UNICEF, 2009).

Furthermore, active learning approach offers a chance to make AIDS education lessons enjoyable. AIDS education classrooms can be constructed to involve quizzes, games or drama, for example - and can still be very effective learning sessions. However, the study agrees with Derebssa (2005) on innovative approaches of teaching and learning employed in a school in Ethiopia found that most teachers still use lecture method in most classes. On the other teachers felt that interactive learning approach should be applied in teaching HIV/AIDS to ensure learners connect HIV issues with real life.

\section{Conclusions and Recommendations}

From the study, the majority of the teachers $89(76.7 \%)$ agreed that question and answer method if appropriately used make learners understand the content HIV/Aids in secondary school. Most teachers identified the use of resource persons as appropriate in teaching HIV/AIDS content in the integrated secondary curriculum. The finding showed that most teachers identified the appropriateness of group discussion in teaching HIV/Aids. Most of the teachers used ICT equipment and software like TV, CDs were appropriate for teaching HIV/AIDS. 


\section{Editon Consortium Journal of Arts, Humanities and Social Studies (ECJAHSS)}

Volume: 01 Issue: 03 | Sep -2019

ISSN: $2663-8525$

Received: 19.07.2019; Accepted 25.07.2019; published: 30.09.2019 at www.editoncpublishing.org

Chesaro, K. D., Editon Cons. J. Arts., Humanit. S. Stud., Double -Blind Peer Reviewed Journal

There was a strong positive relationship between the appropriateness of the teaching strategies employed by teachers and the implementation of the integrated HIV/AIDS education in the Secondary school curriculum $[r=.227, n=116, p<.05]$, this indicated that an increase inappropriateness of the teaching strategies employed by teachers the effective the implementation of the integrated HIV/AIDS education in the Secondary school curriculum. Kinesthetic learning is learning through doing, action, activity, participation preferred by learners as this is the last strategy on the educators' list of preference to teach. Even though learners prefer the kinesthetic- and auditory learning style, educators prefer the visual, nonverbal and verbal style of teaching.

Since classrooms are made of many individual learners, at any given time, learners with all the learning styles are in classrooms. Therefore, while some are dominant, it does not mean a teacher should ignore the less common styles of learning. Teaching is appropriately targeted to address all learning styles and are properly combined and administered the desired outcomes might easily be achieved in an integrated approach to HIV/AIDS education and awareness. Learning can be enhanced when educators use a wide repertoire of teaching styles that could match a wide range of learning styles in their classrooms. Many educators do not necessarily feel comfortable teaching HIV/AIDS-related topics because more often than not, they are forced to bring what is regarded as private into public (sex and the private body). To be able to integrate HIV/AIDS education and awareness into the curriculum, the different teaching and learning styles could be combined to convey the importance of the effects and consequences of HIV/AIDS. Teaching and learning process can be implemented and designed with the aim that learners learn differently, and this important message needs to be conveyed to all learners.

Group work and role-play are particularly important methods in which students might discover the practical aspects of the information they are given. These methods allow students an opportunity to practice and build skills saying "No" to sex. Active learning methods are widely considered one of the most effective methods for young people to learn health-related and social - skills. On the other side, teachers felt that the interactive learning method should be used in teaching HIV/AIDS to make sure learners relate HIV issues with real life.

There was a strong positive relationship between the appropriateness of the teaching strategies employed by teachers and the implementation of the integrated HIV/AIDS education in the Secondary school curriculum. Teaching is appropriately targeted to address all learning styles and are properly combined and administered the desired outcomes might easily be achieved in an integrated approach to HIV/AIDS education and awareness. Learning can be enhanced when educators use a wide repertoire of teaching styles that could match a wide range of learning styles in their classrooms. To integrate HIV/AIDS education and awareness into the curriculum, the different teaching and learning styles could be combined to convey the importance of the effects and consequences of HIV/AIDS.

\section{References}

Alcamo, I. E. (2002). Aids: In the modern world. (pp. 1-85). Williston: Blackwell Publishing. Anderson, E. (2007). Learning styles. Colorado Springs. Colorado: Cook Publishing Company. Baxen, J., \& Breidlid, A. (Eds). (2009). HIV/AIDS in Sub-Saharan Africa: Understanding the implications of culture and context. Cape Town: UCT Press. 


\section{Editon Consortium Journal of Arts, Humanities and Social Studies (ECJAHSS)}

Volume: 01 Issue: 03 | Sep -2019

ISSN: 2663-8525

Received: 19.07.2019; Accepted 25.07.2019; published: 30.09.2019 at www.editoncpublishing.org

Chesaro, K. D., Editon Cons. J. Arts., Humanit. S. Stud., Double -Blind Peer Reviewed Journal

Baxen, J. (2006). What questions? HIV/AIDS Educational research: Beyond more of the same to asking different epistemological questions. University of Cape Town. (Unpublished doctoral thesis).

Bennel, P. (2001). Children and young people in a world of AIDS. UNAIDS Publication 2, 29-3 Perspective. Howorth Press Inc New York USA.

Boler, I., Barlmen, T., \& Doti, K. (2003). The sounds of silence: Difficulties in communicating in HIV/AIDS in Schools. London: Action Aid Hamlyn Hse.

Boler, T., \& Jelema, A. (2005). Deadly inertia: A cross country of education response to HIV/AIDS: Global Campaign for Education. London International Institute for Education Policy.

Brady, L., \& Scully, A. (2005). Engagement: Inclusive classroom management. Australia: Prentice Hall.

Caine, R., \& Caine, G (1991). Making connection: Teaching and the human brain. Alexandria, VA: Association for Supervision and Curriculum Development.

Coffield, F., Moseley, D., Hall, E., \& Ecclestone, K. (2004). Learning styles and pedagogy in post-16 learning: A systematic and critical review. Retrieved on May 8, 2010, from http://www.lsda.org.uk/files/PDF/1543.pdf.

Davis, G. (2007). Conference Report Sex Education of the Young in the Twentieth century. The Gazette. Society for the Social History of Medicine. 36, 4-10.

Derebssa, D. S. (2005). Approaches in Ethiopia primary schools; Monitoring results of Education for all. UNESCO. Addis Ababa Ethiopia.

Dewey, J. (1966). John Dewey selected educational writing. London. Heinemann Educational Books Ltd.

Donald, D., Lazarus, S., \& Lolwana, P. (2006). Educational psychology in social context (3 ${ }^{\text {rd }}$ Ed). Cape Town: Oxford University Press.

Fleming, G. (2009). Learning styles: Know and use your personal learning style. Retrieved on May 8, 2014, from http://hometips.about.com/od/homeworkhelp/a/learningstyle.htm

Gilbert, J., \& Swanier, C. (2008). Learning Styles: How do they fluctuate? Institute for learning styles. Journal of curriculum studies 1, 30-35.

Gross, N., Giaocluinta B., \& Berrestein, M. (1971). Implementing organizational innovations. New York: Basic Books, Inc. Publishing.

Hardee, K., Gay, J., \& Dunn. E. (2009). A practical guide to integrate reproductive health and HIV/AIDS into grant proposal into the global fund. Retrieved on 28 May 2014 from http://www.populationaction.org/pdfs/ia/integration_guide.pdf

Jacobs, H. H. (1997). Mapping the big picture: Integrating curriculum and assessment. Alexandria, VA: Association of Supervision and Curriculum Development.

Kafwa, V. N. (2005). Effectiveness of AIDS Education Programme in Secondary Schools in Busia District (Unpublished M.Phil. Thesis: Moi University).

Kenya Institute of Education (K.I.E.) (1999). AIDS Education Syllabus for Primary Schools. Nairobi. Kenya Literature Bureau. Nairobi Government publishers.

KHRC/RHRA. (2010). Teenage pregnancy and unsafe abortion: The case of Korogocho slums. Nairobi. KHRC. Lockheed, M., \& Verspoor, A. (1999). Improving primary education in developing countries. New York: Oxford University Press. 


\section{Editon Consortium Journal of Arts, Humanities and Social Studies (ECJAHSS)}

Volume: 01 Issue: 03 | Sep -2019

ISSN: $2663-8525$

Received: 19.07.2019; Accepted 25.07.2019; published: 30.09.2019 at www.editoncpublishing.org

Chesaro, K. D., Editon Cons. J. Arts., Humanit. S. Stud., Double -Blind Peer Reviewed Journal

McGill, I., \& Beaty, L. (1995) Action learning: A guide for professional, management and educational development. London: Kogan Page.

MoEST (2004). Development of education in Kenya. Nairobi: Government printer.

Kamo, N., Carlson, M., Robert T., Brennan, \& Earls, F. (2008). Young Citizens as Health Agents: Use of Drama in Promoting Community Efficacy for HIV/AIDS. American Journal of Public Health. 98(2).

Penumal, J. (2008). Student resistance and teacher authority: The demands and dynamics of collaborative learning. Journal of Curriculum Studies. 40(3), 381-398.

Pickett, A. (2010). Reflective teaching practices and academic skills instruction. Retrieved on 30 May 2014 from http://www.indiana.edu/1506/modo2/pickett.html.

Pritchett, L., \& L. H. Summers (1996). Wealthier is Healthier. Journal of Human Resources, 4, 841-868.

Silcock, P., \& Brundrtt, M. (2001). 'The management consequences of different models of teaching and learning.' In Middlewood, D., \& Burton N. (Eds.), Managing the Curriculum. London: Paul Chapman.

UNAIDS. (2002). Report on the Global HIV/AIDS Epidemic December 2002

UNAIDS. (2003). Accelerating action against AIDS in Africa. Geneva: UNAIDS.

UNAIDS. (2004). Global Epidemic Report. Geneva: UNAIDS.

UNAIDS/WHO. (2008). World Wide HIV \& AIDS Statistics Summary. www.unaids.org.

UNESCO. (2005). Educational Radio Project for HIV/AIDS, Trafficking, and Drug use Prevention among Highland Minorities in the Greater Mekong Region. UNESCO, Bangkok. March 2005.

UNESCO. (1990). World Declaration on Education for all Paris UNESCO.

UNESCO. (2003). Promoting Quality Education: Education for Peace, Human Rights and Democracy; Education for Sustainable Development; Curricula, Educational Tools and Teacher Training.

UNESCO. (2009). International guidelines on sexuality education. An evidence-informed approach to effective sex, relationships and HIV/STI education.

UNESCO. (2009). Teachers and HIV/AIDS. Reviewing achievements, identifying challenges.

UNICEF (2009). Global Assessment of UNICEF's Early Childhood Development Kit, https://www.unicef.org/evaluation/files.

Vandemoortele, J., \& Delamonica, E. (2000). The “education vaccine” against HIV. Curr. Comp. Issues Educ. 3

http://www.tc.columbia.edu/cice/volo3nr1/jvedart1.htm.

WCED. (2000). Doing OBE Part $1 \&$ 2. Educator's Manuel. Directorate: Curriculum Studies.

Whiteside, A. \& Sunter C. (2000). AIDS: The Challenges for South Africa. Cape Town: Human \& Rousseau Talelberg.

WHO. (2003). Special Programme on AIDS: The Global Surveillance on AIDS. Unpublished. 